\title{
INCENTIVE RISK IN SERVICE COMPANIES. THEORETICAL APPROACH
}

\author{
ANNA TOKARZ-KOCIK \\ University of Szczecin, Faculty of Management and Economics of Services, POLAND \\ e-mail: anna.tokarz@wzieu.pl \\ RECEIVED \\ ACCEPTED \\ JEL \\ CLASSIFICATION \\ KEYWORDS \\ ABSTRACT \\ 18 January 2018 \\ 2 September 2018 \\ M12, M21, M5 \\ risk, motivating, personnel of service companies \\ The aim of this article is to present the concept of incentive risk, i.e., a risk associated with undertaking incentive \\ activities aimed at shaping employee involvement and attitudes towards the enterprise. The study was per- \\ formed based on desk research method that comprises the analysis of the literature on the subject and reports \\ published in the industry. The article indicates that all decisions concerning the motivation process bear risk, \\ which is most often connected with the lack or an incorrect evaluation of the degree of satisfaction of individual \\ employee needs. In order to lower incentive risk, evaluations in this scope should be constantly carried out, as \\ the hierarchy of incentives for individual employees may be different.
}

\section{Introduction}

A crucial role in developing competitiveness of service companies is played by human capital, which is defined as stock of knowledge, skills, health, and motivation to perform labour, that are possessed by a person. This is a very specific resource of a company. It is characterized by non-transferability of property rights, which means that an employer, through the employment contract, acquires only the right to use, in a certain way, abilities, skills, 
and experiences of employees, but does not become their owner. Therefore, human capital materialized in a given employee should be managed rationally, as it is only at the company's temporary disposal.

The management of human capital on the microeconomic level requires activities undertaken in several fields related to the presence of a person in an organization. Their aim is to optimally utilize work potential in order to increase efficient functioning and the value of an enterprise. There could be distinguished three areas of human capital management in a company (Tokarz-Kocik, 2017, p. 61):

- creation of human capital (planning and choosing personnel),

- development of human capital (training courses),

- shaping employee engagement (motivating).

Each of these areas is related to personnel risk.

Personnel risk is not a homogeneous category, which means that many partial types of risk can be distinguished - one of them is incentive risk that is the subject of the analysis presented in this article.

The aim of this article is to present the concept of incentive risk, i.e., a risk associated with undertaking incentive activities aimed at shaping employee involvement and attitudes towards the enterprise.

The study was performed based on desk research method that comprises the analysis of the literature on the subject and reports published in the industry.

\section{Incentive risk as an element of personnel risk}

Although risk is an ambiguous concept that is difficult to define, it does not always bring negative results, such as failure to obtain the intended goals (effects), deviation from the expected state, incurring higher than expected costs and/or losses. It also brings positive impact - an example of which could be risky activities, which despite the possibility to result in failure, may also constitute a real chance to gain or increase benefits, and be the proof of the entrepreneurship of people who undertake them. By exposing itself to risk, a company may significantly increase its chances to not only survive, but also develop. Therefore, it is not possible to achieve success without taking risk first. Moreover, not taking certain actions may lead to stagnation or even regression.

Modern service companies struggle with various types of risks (e.g., legal, market). One of them is personnel risk that is understood as engagement in activities concerning personnel in conditions of uncertainty (Lipka, 2002, p. 11). It is possible to distinguish several partial types of risks characteristic for individual areas of human capital management, i.e. recruitment, selection, evaluation and incentive risks.

One of the basic tasks of a company is to ensure sufficient level of staff with suitable competences. This is necessary, so that a company can freely react to changes taking place in the environment and adapt to them seamlessly. This area of personnel activities is related to recruitment risk, which results from volatility of phenomena on the labour market, as well as the mismatches of labour demand and supply in terms of quantity and quality. The mentioned phenomena are becoming more and more common due to increasing social mobility, as a result of, among others, Poland's membership in the European Union (Bizon-Górecka, 2009, p. 22). One of the consequences of this phenomenon is the depletion of available labour resources (Tokarz-Kocik, 2016, pp. 947-958).

Selection risk is related to the lack of certainty regarding the accuracy of choosing particular employees as people who can enrich the human resources of the enterprise (Lipka, 2002, p. 56). Therefore, it poses a threat that, instead of qualitative growth of human capital, it will lead to its impoverishment with all the consequences. Selection 
risk occurs regardless of the labour market situation, as even in the case of excess of supply over demand for work, there is never an absolute certainty that the choice of employees is correct. The selection risk level is affected by:

- the HR policy model used (i.e. the sieve or human capital model),

- sampling technique used (where each is associated with specific types of risk),

- selection criteria applied by people performing it.

Another function of human capital management which is subject to higher risk is evaluation. Evaluation risk is related to the probability of incorrect selection of criteria and methods of assessment, inaccurate evaluation of the employee's characteristics, their behaviour at work and the results they bring. Not performing evaluation in order to avoid mistakes is not a good solution, as its result constitutes the starting point for various personnel decisions. When identifying the level of evaluation risk, the degree of objectivity of the evaluation procedures implemented in the company, including the evaluation interview, should be a primary factor.

The risk is also associated with the motivation process. The highest level of risk concerns achievement of a state that is in contrast to incentive activities, i.e. the state of employee demotivation, despite incurring specific expenditures aimed at improving satisfaction of employee needs. This state may result from the failure to detect risks at the operational level, which occur when applying individual salary and non-salary incentive arrangements. In this case, excessive, insufficient, and incorrectly directed effort of managers to shape the attitudes and behaviour of employees may prove to be harmful (Jansen, 2008, p. 266).

Incentive system should not only be consistent with the company's strategy, but also meet the requirements of job applicants (i.e., allow attracting appropriate employees). Failure to comply with any of the requirements increases incentive risk, and thus the risk borne by the employer (McGee, Rennie, 2012, pp. 20-29).

Moreover, decisions regarding investment in employees are subject to a higher risk (e.g., financing training courses), as the rate of return, which is measured by the ratio of profit achieved thanks to employees being the subject of development projects, to the value of the expenditure necessary to achieve it, is always unknown (Becker, 2002, p. 14). Furthermore, investment in employees' development is associated with leaving of employees who were the subject of investment. Despite these threats, not investing in human capital may lead not only to the loss of additional benefits, but also to the decrease in qualification of personnel, who will not be able to achieve the goal set by the company (Brand-Noé, Schwager, 2001, p. 166).

Incentive risk in the service sector is related to the fact that employers with specific human resources cannot be definitively sure of the benefits possible to be achieved thanks to these resources. One reason for that is e.g. the inability to accurately determine a priori the value of all the results of the work performed by employees, as well as the effects of actions taken against them, including the results of the adopted incentive methods. Incentive risk may result not only from the company's activities, but also from employees' behaviours. It concerns the risk of losing key company skills due to the turnover of employees, who are difficult to replace because of their qualifications (Knaese, Probst, 2001, p. 36).

Summarizing the concept and partial types of personnel risk, it should be concluded that this risk is strongly associated with incentive activities. The failures incurred in this area automatically involve failures in other areas of human capital management in the enterprise. Improper motivation in the company:

- leads to failures in recruitment and selection processes (as specialists with the highest qualifications do not apply to the company), 
- reduces the effectiveness of the company's activities (as employees are not motivated enough to develop and work with full commitment),

- negatively affects the loyalty of employees and contributes to the increase in staff turnover.

In case of incentive risk, the risked value (subject to risk) may take tangible (increased personnel costs, lower profit, loss of competitiveness) or intangible form (loss of good image, reputation), whereas the latter also has financial implications.

\section{Satisfaction of employees as a result of inducement}

Job satisfaction is a positive emotional state resulting from the evaluation of own work or experiences related to it (Woźniak, 2012, p. 52). It is also understood as positive attitudes and emotions of a person towards working environment and professional duties performed by them (Staples, Higgins, p. 215). Satisfaction is the resultant of the difference between what the employee receives at work and what they think they should receive.

Job satisfaction as a result of inducement is experienced when the value achieved by the employee as a result of work is equal to the expected value, because of which the work was undertaken. Therefore, it depends on the balance between what a person invests in a performed work (e.g., time, involvement) and what they receive in return (promotion, remuneration, opportunity for development, peer relations). Lack of satisfaction occurs when serious employee involvement is rewarded with small benefit.

Satisfaction at a work place is related to the possibility of meeting needs, aims, values and beliefs by an employee (Bartkowiak, 2009, p. 116). Such possibility of realizing one's values and goals is perceived as the basis for shaping the employee's attitude towards their work. V.H. Vroom believed that a positive attitude towards work equals job satisfaction, which is contingent on fulfilling the expectations of the employee (Vroom, 1964, p. 99). He assumed that employee satisfaction results from:

- the value of the expected reward,

- effort put to achieve the desired result,

- perception of the subjective probability of success,

- evaluation of the validity of the reward received,

- comparison of rewards with social standards.

Further development of this concept could be found in works by E.A. Locke, who indicates the following conditions work must fulfil to satisfy the employee (Locke, 1976, p. 1328; Springer, 2011, p. 164):

- work is an intellectual challenge for an employee that they can deal with,

- alignment of own goals with the company's goals,

- lack of excessive physical overload (work tailored to an employee's ability),

- fair remuneration adequate to individual aspirations,

- physical working conditions that allow achieving goals and are in line with the needs of an employee,

- respecting other employees of the organization,

- support in combining individual and professional goals, minimizing conflict and ambiguity of roles.

According to E.A. Locke, job satisfaction is the result of appraisal of one's work, which makes it possible to achieve important values from job, provided that they are in line with basic human needs or help to achieve them. 
In today's companies, there is general recognition that care for employee satisfaction will also translate into positive behaviour expected by the employer, i.e. low absenteeism, commitment to work and loyalty. Whereas, a decrease in satisfaction will significantly increase the risk of unfavourable phenomena.

The results of the research conducted so far confirm that the lack of job satisfaction is associated with:

- higher absenteeism rates (Dwyer, Ganster, 1991, pp. 609-620),

- greater turnover of employees (Jenkins, 1993, pp. 83-91),

- reduced quality of services provided by the company (Malhotra, Mukherjee, 2004, pp. 162-174).

When managing job satisfaction and reducing personnel risk, of great importance are incentive activities undertaken by a service company.

\section{Importance of incentive activities in the reduction of personnel risk}

There are two entities that take part in the motivation process, i.e., an employee (motivated) and a superior (motivating). An element connecting them is a relationship whose type and effect depend on both the superior and the employee, with each side having an impact on the success of the process (Pietroń-Pyszczek, 2005, p. 497).

It is very difficult to achieve agreement between an employee and an employer as to undertaken incentive activities. On the one hand, an employer expects the employee to be committed and responsible for the tasks entrusted to them and to use all their skills at work. On the other, an employee can expect the employer to appreciate their involvement and provide them with adequate remuneration (in the form of tangible or intangible incentives).

Properly carried out incentive activities in a service company should meet financial, psychological and social needs of employees. Incentives used in service companies should complement each other, as a properly constructed motivational system should lead to a synergy effect, where the effectiveness of the entire system is greater than the sum of the effectiveness of its individual components.

Selected incentive tools ensure the appropriate level of involvement of employees, which affects the effectiveness of individual activities, work of the entire team, and in consequence, also the results achieved by a service company. Such tools constitute the following incentives:

a) financial:

- ownership (employee shares, profit-sharing),

- earnings (remuneration, bonuses, service premium, financial bonuses);

b) non-financial:

- tangible (medical care, insurance, retirement insurance, telephone/computer/company car, social benefits, training courses),

- intangible (praise, possibility of promotion, work comfort, job security).

Financial incentives include basic salary, bonuses, rewards, and possible functional allowances, commissions. A special role in binding an employee to a company is attributed to shares and stocks, as they provide long-lasting loyalty. These are deferred income, whose value depends on company's market value. Of special importance are also financial service packages, and preferential loans through which the company tries to support employees in meeting their needs.

When designing remuneration system, it is important to pay attention to whether components of remuneration and remuneration policies are tailored to the needs of the employees and the employer (a service company). In remuneration management, there can be observed a trend to liberalize salaries and introduce cafeteria plans 
of remuneration, which allow an employee to individually compose a set of additional non-financial benefits. The introduction of an effective system of additional incentives to an enterprise requires, however, achieving an adequate level of satisfaction with the remuneration received so far by employees.

Non-financial benefits may be of tangible character (e.g., a cell phone, medical cares) or intangible (career planning, organizational climate, prestige of the profession, recognition by the team and company's management, autonomy in the implementation of tasks, general image of the enterprise). Non-financial incentives shape employee awareness, their attitude towards work and supervisors, as well as mutual relationships. They encourage employees to take on more ambitious tasks, increase productivity and quality of work, abandon the attitude of passivity and assurance, and become committed and willing to cooperate.

Implementation of a system that includes on wider scale non-financial incentives requires from a service company's CEO to act systematically and be more diligent, as well as truly respect employees and invest in organizational human capital.

Undoubtedly, the advantage of non-financial solution is that a budget necessary for their implementation is lower than the one planned to be spent on remuneration. Therefore, it is possible to, in a less costly manner, affect self-esteem, increase loyalty, and strengthen identification of employees with a service company. Moreover, nonfinancial incentives support financial incentives in generating long-term relationships with employees based on mutual trust and benefits. One of the best investments is to foster attachment of qualified employees to a service company. It especially important in the era of fierce competition, where on the one hand, it is difficult to acquire competent employees on the market, and on the other, training new employees is a long-term process that will take time before they reach (sometimes after many months or even years) a skill level that is satisfying for a service company.

The result of properly chosen incentives is job satisfaction experienced by employees (Harris, Mowen, Brown, 2005, pp. 19-35). Great concern for employee satisfaction results in tangible benefits for a service company, such as:

- great involvement of employees in the performance of duties (high quality of services; strengthening of the company's market position),

- loyalty of employees (low employee turnover),

- a positive image of a service company as an employer.

The level of employee commitment is a consequence of exchange of benefits between them and a service company. Therefore, effective motivation of employees requires conclusion of a psychological contract in a company, which includes two components: transactional and relational that interact with one another (Guzzo, Noonan, 1994, pp. 447-462). In return for the effective involvement of employees in the provision of services, a service company should:

- ensure a sense of security,

- invest in their development,

- fairly appreciate their contribution,

- create conditions in which work will be a challenge and pleasure, and employees will be aware that their contribution is important for the organization.

The possible disturbance of transactional agreement balance causes a disturbance in relations, which, in turn, negatively affects the involvement of employees, who are one of the main stakeholders 
of a service company, i.e. people who influence its activities, benefit from the company's success, and bear the consequences of failures and errors.

Classical incentive schemes refer to external stimulus factors, such as: higher salaries, promotions, and better working environment conditions. Today, in many cases, there can be observed a crisis in this sphere, as instead of comprehensively motivating, they discourage to develop, block initiative, eliminate enthusiasm, weaken organizational culture, etc. External goal orientation is so strong that it suppresses internal motivation, work becomes only an obligation, psychological withdrawal of the employee and burnout take place, and thus professional activity is hindered. Extrinsic incentives are caused by factors related to the job environment and conditions, whereas intrinsic incentives are triggered by factors resulting from the work itself and the achieved professional successes. Each of these groups of factors has a different impact on engagement. F.W. Herzberg, not without reason, described external factors as "hygiene factors" - important, but not decisive for employee involvement. He also noticed that extrinsic factors are very often the source of lack of job motivation, due to absence of satisfaction, or cause neutral, indifferent state (Herzberg, 2006, p. 9).

The process of motivating employees in service companies should therefore consist of two phases. In the first one, the so-called hygiene factors, i.e. safe work, satisfying salary, appropriate interpersonal relationships and acceptable managerial style, should be provided. However, this is enough to only eliminate dissatisfaction. In order to obtain the employee's true involvement, intrinsic factors leading to job satisfaction should be used by enriching the content of the work, expressing recognition, and creating career perspectives. Although extrinsic factors may have an immediate impact on employee behaviour, their impact does not have to be long-term. On the other hand, intrinsic factors have a profound and long-lasting impact on employee behaviour. Both types of factors are equally important in the scope of satisfying a wide range of employees' needs. Therefore, achieving effective engagement requires finding the right balance between extrinsic incentives (salary increases, promotions, rewards) and intrinsic incentives, such as increased independence, development opportunities, sense of achievement, and various forms of participation.

Due to the fact that employee expectations change, whereas incentive system rules are formalized and naturally unvarying, it is necessary to systematically verify incentive activities related to identification of occurring irregularities.

\section{Conclusions}

All decisions concerning the motivation process are subject to risk, which is most often related to the lack or invalid evaluation of the level of satisfaction of individual employee needs. In this context, it is important to minimize negative consequences of the lack of coherence in personnel activities in the area of motivation, by creating a coherent system of financial and non-financial incentives directing the behaviour of subordinates. In order to reduce incentive risk, it is necessary to constantly carry out diagnoses in this area, since the hierarchy of incentives for individual employees may be different. Therefore, service companies should:

- set individual procedures for assessing the effectiveness of the motivation process,

- identify dysfunctions of the motivation process, using the results of periodic assessments of personnel,

- carry out a systematic analysis of employees' expectations and aspirations.

Only by recognizing employees' needs and tailoring to them incentive methods, can an employer effectively manage their subordinate staff. The response will be an increase in employee involvement in the process 
of performing tasks. Such an approach will allow service entrepreneurs to reduce personnel risk and provide a chance to achieve market success.

\section{References}

Bartkowiak, G. (2009). Człowiek w pracy. Od stresu do sukcesu w organizacji. Warszawa: PWE.

Becker, M. (2002). Personalentwicklung: Bildung, Förderung und Organisationsentwicklung in Theorie und Praxis. Stuttgart: SchäfferPoeschel Verlag.

Bizon-Górecka, J. (2009). Migracje ludności jako czynnik wzrostu ryzyka personalnego w przedsiębiorstwie. In: A. Lipka, S. Waszczak (eds.), Koszty jakości zarządzania kapitałem ludzkim a ryzyko personalne. Katowice: Prace Naukowe Akademii Ekonomicznej w Katowicach.

Brand-Noé, C., Schwager, E. (2001). Die Prüfung von High-Potential-Programmen: Beitrag der Revision zur Zukunftssicherung des Unternehmens. Personal, 162-167.

Dwyer, D.J., Ganster, D.C. (1991). The Effects of Job Demands and Control on Employee Attendance and Satisfaction. Journal of Organizational Behavior, 12, 609-620.

Guzzo, R.A., Noonan, K.A. (1994). Human resource practices as communications and the psychological contract. Human resource management, 33 (3), 447-462.

Harris, E.G., Mowen, J.C., Brown, T.J. (2005). Re-examining Salesperson Goal Orientations: Personality Influencers, Customer Orientation, and Work Satisfaction. Journal of the Academy of Marketing Science, 33 (1), 19-35.

Herzberg, F.W. (2006). Raz jeszcze o motywowaniu pracowników. Harvard Business Review Polska, 7-8, 9.

Jansen, T. (2008). Personalcontrolling. Ludwigshafen: Friedrich Kiehl Verlag.

Jenkins, J.M. (1993). Self-Monitoring and Turnover: The Impact of Personality on Intent to Leave. Journal of Organizational Behavior, 14, 83-91.

Knaese, B., Probst, G. (2001). Wissensorientiertes Management der Mitarbeiterfluktuation. Zeitschrift für Organisation, 1, 34-49.

Lipka, A. (2002). Ryzyko personalne: szanse i zagrożenia zarządzania zasobami ludzkimi. Warszawa: Poltext.

Locke, E.A. (1976). The Nature and Causes of Job Satisfaction. Handbook of Industrial and Organizational Psychology. Chicago: Rand McNally College Publishing Company .

Malhotra, N., Mukherjee, A. (2004). The relative influence of organizational commitment and job satisfaction on service quality of customer-contact employees in banking call centers. Journal of Services Marketing, 18, 162-174.

McGee, R., Rennie, A. (2012). Budowanie zaangażowania pracowników. Warszawa: ABC a Wolters Kluwer business.

Pietroń-Pyszczek, A. (2005). Proces motywowania w przedsiębiorstwach - przesłanki i kierunki zmian. In: A. Pocztowski (ed.) Praca i zarządzanie kapitałem ludzkim w perspektywie europejskiej. Kraków: Oficyna Ekonomiczna.

Springer, A. (2011). Wybrane czynniki kształtujące satysfakcję pracownika. Problemy Zarządzania, 4/1 (34), 162-180.

Staples, D.S., Higgins, C.A. (1998). A study of the impact of factor importance weightings on job satisfaction measures. Journal of Business and Psychology, 13 (2), 211-232.

Tokarz-Kocik, A. (2016). Procesy demograficzne jako determinanta zachowań pracodawców w branży hotelarskiej w Polsce, Marketing i Rynek, 3, 947-958.

Tokarz-Kocik, A. (2017). Ryzyko motywacyjne w gospodarowaniu kapitałem ludzkim w hotelarstwie. Ujęcie ekonomiczne. Szczecin: Wydawnictwo Naukowe Uniwersytetu Szczecińskiego.

Vroom, V.H. (1964). Work and Motivation, New York: Wiley.

Woźniak, J. (2012). Współczesne systemy motywacyjne: teoria i praktyka. Warszawa: Wydawnictwa Profesjonalne PWN.

Cite this article aS: Tokarz-Kocik, A. (2018). Incentive risk in service companies. Theoretical approach. European Journal of Service Management, 3 (27/2), 475-482. DOI: 10.18276/ejsm.2018.27/2-58. 